\title{
KOMBINASI REBUSAN DAUN SALAM DAN KEMANGI DALAM MENURUNKAN KADAR ASAM URAT Mus musculus
}

\author{
Combination Of Bay And Basil Leaves To Decrease The Mus Musculus \\ Uric Acid Levels
}

\author{
1*Fahlia Nirmala, ${ }^{2}$ Kholifatuz Zumaroh, ${ }^{3}$ Novia Afriani Donatomo, ${ }^{4}$ Khoirul Ngibad \\ ${ }^{1}$ Universitas Maarif Hasyim Latif Sidoarjo, Jl. Raya Ngelom Megare No.30, Ngelom, Kec. Taman, Sidoarjo, Indonesia \\ ${ }^{2}$ Universitas Maarif Hasyim Latif Sidoarjo, Jl. Raya Ngelom Megare No.30, Ngelom, Kec. Taman, Sidoarjo, Indonesia \\ ${ }^{3}$ Universitas Maarif Hasyim Latif Sidoarjo, Jl. Raya Ngelom Megare No.30, Ngelom, Kec. Taman, Sidoarjo, Indonesia \\ ${ }^{4}$ Universitas Maarif Hasyim Latif Sidoarjo, Jl. Raya Ngelom Megare No.30, Ngelom, Kec. Taman, Sidoarjo, Indonesia
}

\author{
*e-mail : fahlia-nirmala@student.umaha.ac.id
}

\begin{abstract}
ABSTRAK
Indonesia termasuk negara dengan sumber keanekaragaman hayati paling besar di dunia. Khusunya daun salam (Syzygium polyanthum) dan daun kemangi (Ocimum basilicum) dapat ditanam di area pekarangan rumah. Tumbuhan tersebut memiliki banyak khasiat salah satunya dapat digunakan sebagai penurun asam urat darah. Tujuan penelitian ini adalah untuk mengetahui dosis optimum yang dapat menurunkan kadar asam urat dengan pemberian kombinasi rebusan daun kemangi dan daun salam dan mengetahui golongan senyawa fitokimia dapat menurunkan kadar asam urat pada daun kemangi dan daun salam. Pada penelitian ini telah dilakukan pengujian aktivitas antihiperurisemia rebusan daun salam dan daun kemangi pada Mus musculus) dengan garis keturunan Balb/C jenis kelamin jantan, umur 8 - 10 minggu untuk mengungkapkan efektivitas daun salam dan daun kemangi sebagai penurun asam urat darah. Dosis rebusan yang digunakan adalah 1,5 gelas, 1 gelas, dan 0,5 gelas dari menyusutnya air rebusan yang awalnya 2 gelas. Pengujian dilakukan pada mencit yang mengalami hiperurisemia yang diinduksi kalium oksonat dengan dosis $250 \mathrm{mg} / \mathrm{kg}$ BB atau $5 \mathrm{mg} / 20 \mathrm{~g}$ BB pada Mus musculus secara intraperitoneal dan campuran hati ayam, kecambah dan mlinjo. Pengukuran kadar asam urat dilakukan dengan menggunakan metode POCT (Point Of Care Tasting). Hasil penelitian menunjukkan bahwa air kombinasi rebusan daun salam dan daun kemangi terbukti dapat mengakibatkan penurunan kadar asam urat dalam darah mencit sekitar 0,5-1,0 mg/dl. Aktivitas tersebut efektif pada kedua dosis yaitu 0,5 gelas dan 1,5 gelas namun untuk mendapatkan penurunan kadar asam urat yang signifikan air rebusan ini harus dikonsumsi secara rutin dan waktu yang lebih lama.
\end{abstract}

Kata kunci : daun salam, daun kemangi, asam urat, herbal

\begin{abstract}
Indonesia is one of the world's largest of biodiversity. Especially bay leaves (Syzygium polyanthum) and basil leaves (Ocimum basilicum). These plants can be used to reduce blood uric acid. This study aimed to determine the optimum dose that could reduce uric acid levels by providing a combination of decoction of basil leaves and bay leaves and to knew the phytochemical compounds that could reduce uric acid levels in basil leaves and bay leaves. The antihiperuricemia activity of boiled bay leaves and basil leaves was tested on male sex mice (Mus musculus) Balb / C strain, aged 8-10 weeks to reveal the effectiveness of bay leaves and basil leaves as blood uric acid-lowering. The dosage of decoction used is 1.5 glasses, 1 glass, and 0.5 glass from the shrinking of the cooking water which was originally 2 glasses. Tests were carried out on mice that experienced hyperuricemia induced by potassium oxonate $250 \mathrm{mg} / \mathrm{kg} \mathrm{BW}$ or $5 \mathrm{mg} / 20 \mathrm{~g} \mathrm{BB}$ in mice intraperitoneally and mixed chicken liver, sprouts and melinjo. Measuring the level of urate is done using the POCT (Point Of Care Tasting) method. The results showed that combination of boiled bay leaves and basil leaves could reduce blood uric acid levels in mice around $0.5-1.0 \mathrm{mg} / \mathrm{dl}$. The activity was effective in both doses, 0.5 glass and 1.5 glasses, but to get a significant decrease in uric acid levels this cooking water had to be consumed regularly and for a longer time.
\end{abstract}

Keyword: bay leaves (Syzygium polyanthum), basil leaves (Ocimum basilicum), uric acid, herbs 


\section{PENDAHULUAN}

Indonesia mempunyai keanekaragaman hayati paling tinggi ke 2 di dunia setelah Brazil. Indonesia memiliki 30.000 jenis flora dengan 940 jenis berkhasiat dijadikan obat dan telah digunakan sebagai obat tradisional (Darussalam \& Rukmi, 2016). Berdasarkan data hasil penelitian pendahuluan yang dilaksanakan di Puskesmas Cerme Kab. Gresik penderita gout mulai bulan Januari sampai dengan bulan September 2017 terdapat sebanyak 341 penderita gout. Pada penelitian pendahuluan yang dilakukan penelitian pada tanggal 02 Oktober 2017 dengan wawancara terhadap 5 orang yang mengalami gout yang memeriksakan dirinya di Puskesmas Cerme didapatkan bahwa mereka semua mengalami peningkatan kadar (level) asam urat dengan nilai 7,5 $\mathrm{mg} / \mathrm{dl}, 7,8 \mathrm{mg} / \mathrm{dl}, 8 \mathrm{mg} / \mathrm{dl}, 8,2 \mathrm{mg} / \mathrm{dl}$ dan $9 \mathrm{mg} / \mathrm{dl}$ (Effendi, 2017).

Asam urat merupakan asam yang berbentuk kristal-kristal yang berasal dari hasil akhir dari proses metabolisme purin. Purin tersebut merupakan bagian asam nukleat yang terkandung pada inti sel-sel tubuh (Lehninger, 1982). Asam urat merupakan zat hasil akhir metabolisme purin dalam tubuh yang dibuang melalui urine. Peningkatan kadar (level) asam urat dalam darah yang melewati batas normal akan mengakibatkan terjadinya hiperurisemia yang apabila berkepanjangan akan menyebabkan penyakit gout. Penyakit hiperurisemia dapat disebabkan oleh adanya peningkatan proses metabolisme asam urat atau dikenal dengan istilah overprotection, penurunan pengeluaran asam urat urin atau dikenal dengan istilah underexcretion atau kombinasi antara keduanya. Penyakit hiperurisemia berhubungan erat dengan pola makan seseorang yang memakan makanan dengan banyak kandungan purin (Utami \& Lentera, 2014).

Produksi asam urat yang meningkat diakibatkan oleh karena kecepatan biosintesa purin pada proses pembentukan DNA dan RNA. Hal ini disebabkan oleh adanya gangguan produksi enzim. Gangguan tersebut dikarenakan oleh produksi enzim HGPRT atau Hipoxantin Guanine Fosforibosil Transferase yang menurun dan produksi enzim PRPP atau Fosforibosil Piro Fosfatase yang meningkat yang mengakibatkan terjadinya anomaly metabolisme purin. Enzim xantin oksidase membantu produksi asam urat dengan hasil samping berupa radikal bebas. Kekurangan enzim HGPRT bisa mengakibatkan akumulasi PRPP. Selain itu, penggunaan enzim PRPP dalam inhibisi umpan balik juga dapat menurun yang menyebabkan terjadinya penggunaan semua hipoxantin guna memproduksi asam urat (Kusumayanti, et al., 2014).

Salah satu tanaman yang diduga berkhasiat dalam menyembuhkan asam urat adalah daun salam dan daun kemangi. Daun salam dapat digunakan untuk menurunkan kolesterol tinggi. Selain itu, juga dapat mengobati sakit maag, kencing manis, tekanan darah tinggi, dan diare (Ningtiyas \& Ramadhian, 2016).

Secara umum senyawa flavonoid dapat ditemukan dibagian daun maupun bunga pada suatu tanaman (Saifudin, 2014). Kandungan flavonoid ini yang mampu menghambat kerja enzim hipoxantin dan xantin dalam tubuh sehingga dapat menghambat pembentukan asam urat. Selain itu juga berkhasiat sebagai diuretik yang mampu mengeluarkan asam urat memalui urin (Andriani \& Chaidir, 2016).

Pada penelitian sebelumnya, menunjukkan bahwa air rebusan dari daun salam mampu menurunkan kadar (level) asam urat, dengan uji Wilcoxon menunjukan nilai signifikan 0.009 $(\mathrm{p}<0.05)$, yang bermakna terdapat perbedaan antara sebelum pemberian air rebusan dari daun salam dan sesudah pemberian air rebusan dari daun salam (Darussalam \& Rukmi, 2016). Di sisi lain, penelitian yang dilakukan oleh Ismanto \& Masi (2016) menunjukkan bahwa air rebusan dari daun kemangi mampu menurunkan kadar atau level asam urat pada penderita hiperurisemia di Puskesmas Wolaang dengan pemberian air rebudan dari daun kemangi selama 7 hari.

Karena belum ada penelitian tentang kombinasi rebusan daun kemangi dan daun salam beserta dosisnya sehingga penelitian ini mempunyai tujuan utaman untuk mengetahui dosis optimum yang dapat menurunkan kadar (level) asam urat dengan pemberian kombinasi rebusan daun kemangi dan daun salam. Penelitan mengenai kombinasi 2 tanaman sudah banyak dilakukan yang salah satunya adalah mengenai potensikombinasi ekstrak etanol 
daun bunga matahari dan tanaman anting-anting untuk mengatasi penyakit anti malaria secara in vivo (Ngibad, 2019). Dengan adanya kombinasi diharapkan agar mendapatkan sebuah dosis yang lebih efektif untuk penurunan kadar asam urat.

\section{METODE PENELITIAN}

Jenis penelitian yang digunakan berupa eksperimen laboratorium kemudian data dianalisis secara statistik dengan menggunakan uji normalitas dan homogenitas. Data yang normal dan homogen tersebut dilanjutkan uji parametrik ANNOVA One Away untuk mengetahui nilai sig dan dilanjutkan dengan Uji Post Hoe Bonferroni sehingga diketahui kelompok perlakuan yang mempunyai perbedaan dan baik untuk menurunkan asam urat.

\begin{abstract}
Alat
Panci, kompor, saringan, gelas, sendok sayur, spuit oral, gunting bedah, pipet ukur, pipet pasteur, gelas beaker, stik test asam urat, POCT (Point Of Care Testing).
\end{abstract}

\section{Bahan}

Daun kemangi (Ocimum basilicum) dan daun salam (Syzygium polyanthum), air PDAM, aquades, Reagen Wagner, Reagen Mayer, Metanol 50\%, logam Mg, $\mathrm{HCl}$ pekat (37\%), $\mathrm{HCl} 2 \%, \mathrm{HCl} 0,05 \mathrm{M}, \mathrm{HCl} 1 \mathrm{~N}$, Kloroform, Aseton, Etanol p.a, Asam Asetat Anhidrat, larutan $\mathrm{FeCl}_{3} 1 \%, \mathrm{H}_{2} \mathrm{SO}_{4}$ p.a., Dietil Eter p.a, CMC Na 1\%, Allopurinol, Kalium Oksonat.

\section{Pembuatan kombinasi rebusan}

Pembuatan kombinasi rebusan daun salam dan daun kemangi dibuat menjadi 3 dosis yaitu:

1. Daun salam sebanyak 15 lembar dan daun kemangi sebanyak 15 pucuk dimasukkan ke dalam panci. Kemudian ditambahkan air sebanyak 2 gelas dan dipanaskan hingga air menjadi $1 \frac{1}{2} 2$ gelas. Kemudian air rebusan dari daun salam dan daun kemangi didinginkan.

2. Sebanyak 15 lembar daun salam dan 15 pucuk daun kemangi dimasukkan kedalam panci. Kemudian tambahkan air sebanyak 2 gelas dan dipanaskan hingga air menjadi 1 gelas.
Kemudian air rebusan daun salam dan daun kemangi didinginkan.

3. Sebanyak 15 lembar daun salam dan 15 pucuk daun kemangi dimasukkan kedalam panci. Kemudian tambahkan air sebanyak 2 gelas dan dipanaskan hingga air menjadi $1 / 2$ gelas. Kemudian air rebusan daun salam dan daun kemangi didinginkan.

\section{Uji aktivitas hiperurisemia}

Penelitian ini menggunakan hewan coba Mus musculu) garis keturunan $\mathrm{Balb} / \mathrm{C}$, umur $8-10$ minggu. Penelitian dilakukan dengan enam kelompok perlakuan. Total sampel dari masing-masing kelompok perlakuan ditentukan berdasarkan rumus Federer (Felicia, 2009).

Rumus Federer: $(\mathrm{n}-1)(\mathrm{t}-1) \geq 15$

$$
\begin{aligned}
& \text { dengan } \mathrm{t}=\text { total kelompok }=6 \\
& \mathrm{n} \quad \mathrm{j} \text { jumlah pengulangan tiap } \\
& \text { sampel } \\
& (\mathrm{n}-1)(6-1) \geq 15 \\
& (\mathrm{n}-1) 5 \geq 15 \\
& 5 \mathrm{n}-5 \geq 15 \\
& 5 \mathrm{n} \geq 20 \text { maka, } \mathrm{n} \geq 4
\end{aligned}
$$

Berdasarkan perhitungan tersebut maka total sampel minimal yang digunakan adalah 4ekor mencit untuk setiap kelompok perlakuan. Sehingga jumlah minimal seluruh sampel yang dipakai adalah 24 ekor mencit. Pada penelitian ini, tiap kelompok perlakuan dilebihkan 2 mencit, sehingga jumlah mencit yang digunakan adalah 36 mencit.

Sebelum perlakuan, Mus musculus dipelihara dalam kendang. Alas kandang dibuat dari serbuk kayu. Kandang ditutup dengan anyaman kawat. Mus musculus diberi makan dan minum secara ad libitum setiap hari. Penelitian menggunakan enam kelompok perlakuan. Ketentuan dari tiap-tiap kelompok adalah sebagai berikut:

1. KN : Kontrol normal, tidak diberi perlakuanapapun.

2. K- : Kontrol negatif, diberi suspensi CMC $\mathrm{Na} 1 \%$ secara per oral.

3. $\mathrm{K}+$ : Kontrol positif, diberi suspensiallopurinol $10 \mathrm{mg} / \mathrm{kg}$ BB secara per oral. 
4. P1 : Rebusan daun salam dan daun kemangi dari2 gelas air hingga tersisa 1 gelas, di injeksi sebanyak $1 \mathrm{ml}$.

5. P2 : Rebusan daun salam dan daun kemangi dari2 gelas air $\mathrm{s}$ hingga tersisa $3 / 4$ gelas, di injeksi sebanyak $1 \mathrm{ml}$.

6. P3 : Rebusan daun salam dan daun kemangi dari2 gelas air hingga tersisa $1 \frac{1}{2}$ gelas, di injeksi sebanyak $1 \mathrm{ml}$.

Induksi hiperurisemia dilakukan dengan pemberian campuran pakan melinjo, hati sapi dan kecambah yang ditambahkan pada pakan mencit selama 22 hari. Pada hari ke-17 hingga hari ke-22 diberi perlakuan sesuai kelompok. Pada hari ke-14 dilakukan penginduksian kalium oksonat $250 \mathrm{mg} / \mathrm{kg}$ BB atau $5 \mathrm{mg} / 20 \mathrm{~g}$ BB pada mencit (Zhao et al, 2005) secara intraperitoneal untuk semua kelompok perlakuan. Setelah mencit mengalami hiperurisemia dilakukan penginduksian air rebusan kombinasi daun salam dan daun kemangi secara oral selama satu minggu kemudian dilakukan pengambilan darah mencit pada vena lateral dengan cara memotong bagian ujung ekor mencit. Penetapan kadar asam urat diukur dengan metode POCT (Point Of Care Tasting).

\section{Uji Penapisan Fitokimia}

Uji fitokimia dilakukan terhadap air rebusan dari daun salam dan daun kemangi untuk mengetahui adanya kandungan senyawametabolit sekunder seperti golongan senyawaalkaloid, flavonoid, saponin, tanin, triterpenoid (Ngibad, 2019).

\section{HASIL DAN PEMBAHASAN}

\section{Hasil}

Hasil analisis fitokimia menggunakan reagen pada rebusan daun salam ditunjukkan pada Tabel 1 dan hasil analisis fitokimia menggunakan reagen pada rebusan daun salam ditunjukkan pada pada Tabel 2.

TABEL 1. Hasil Analisis Fitokimia Air Rebusan Daun Salam

\begin{tabular}{cccc}
\hline Uji Analisis & Pereaksi & Pengamatan & Hasil \\
\hline
\end{tabular}

\begin{tabular}{|c|c|c|c|}
\hline \multirow[t]{2}{*}{ Alkaloid } & 1. Mayer & 1. Endapan putih & - \\
\hline & 2. Wagner & $\begin{array}{l}\text { 2. Endapan coklat } \\
\text { kemerahan }\end{array}$ & \\
\hline Flavonoid & $\begin{array}{l}\text { Aseton + Asam Borat } \\
+ \text { Asam Oksalat + } \\
\text { Eter }\end{array}$ & $\begin{array}{l}\text { Fluoresensi kuning } \\
\text { intensif }\end{array}$ & + \\
\hline Tanin & $\mathrm{FeCl}_{3} 10 \%$ & $\begin{array}{l}\text { Biru tua atau hitam } \\
\text { kehijauan }\end{array}$ & - \\
\hline Saponin & $\mathrm{HCl} 2 \mathrm{~N}$ & $\begin{array}{l}\text { Adanya busa yang } \\
\text { stabil }\end{array}$ & - \\
\hline Triterpenoid & Liebermann-Burchard & $\begin{array}{l}\text { Cincin kecoklatan } \\
\text { atau violet }\end{array}$ & + \\
\hline
\end{tabular}

TABEL 2. Hasil Analisis Fitokimia Air Rebusan Daun

\begin{tabular}{|c|c|c|c|}
\hline $\begin{array}{c}\text { Uji Analisis } \\
\text { Fitokimia }\end{array}$ & Pereaksi & Pengamatan & Hasil \\
\hline Alkaloid & $\begin{array}{l}\text { 1. Mayer } \\
\text { 2. Wagner }\end{array}$ & $\begin{array}{l}\text { 1. Endapan putih } \\
\text { 2. Endapan coklat } \\
\text { kemerahan }\end{array}$ & - \\
\hline
\end{tabular}

\begin{tabular}{|c|c|c|c|}
\hline Flavonoid & $\begin{array}{l}\text { Aseton + Asam Borat } \\
+ \text { Asam Oksalat }+ \\
\text { Eter }\end{array}$ & $\begin{array}{l}\text { Fluoresensi kuning } \\
\text { intensif }\end{array}$ & + \\
\hline Tanin & $\mathrm{FeCl}_{3} 10 \%$ & $\begin{array}{l}\text { Biru tua atau hitam } \\
\text { kehijauan }\end{array}$ & - \\
\hline Saponin & $\mathrm{HCl} 2 \mathrm{~N}$ & $\begin{array}{l}\text { Adanya busa yang } \\
\text { stabil }\end{array}$ & - \\
\hline Triterpenoid & Liebermann-Burchard & $\begin{array}{l}\text { Cincin kecoklatan } \\
\text { atau violet }\end{array}$ & + \\
\hline
\end{tabular}

Hasil uji anti-hiperurisemia ditunjukkan pada Tabel 3 dan Tabel 4.

TABEL 3. Kadar Asam Urat Mencit untuk Kontrol Normal, Negatif Dan Positif

\begin{tabular}{ccc}
\hline \multirow{3}{*}{ Keterangan } & $\begin{array}{c}\text { Kadar asam urat } \\
\text { mencit Sebelum } \\
\text { Perlakuan (mg/dl) }\end{array}$ & $\begin{array}{c}\text { Kadar asam urat } \\
\text { mencit sesudah } \\
\text { Perlakuan (mg/dl) }\end{array}$ \\
\cline { 2 - 3 } Kontrol Normal & 1,2 & 1 \\
\cline { 2 - 3 } & 1 & 1,1 \\
\cline { 2 - 3 } & 0,7 & 0,6 \\
\hline \multirow{3}{*}{ Kontrol Negatif } & 1,1 & 1,1 \\
\cline { 2 - 3 } & 3,4 & 3,3 \\
\cline { 2 - 3 } & 4,3 & 4,3 \\
\hline \multirow{3}{*}{ Kontrol Positif } & 3,4 & 3,4 \\
\cline { 2 - 3 } & 3,6 & 3,6 \\
\cline { 2 - 3 } & 5,4 & 2,4 \\
\cline { 2 - 3 } & 6,5 & 5,1 \\
\hline
\end{tabular}

TABEL 4. Kadar Asam Urat Mencit untuk Perlakuan

\begin{tabular}{cccc}
\hline \multirow{2}{*}{$\begin{array}{c}\text { Jenis } \\
\text { perlakuan }\end{array}$} & \multicolumn{3}{c}{ Kadar asam urat mencit (mg/dl) } \\
\cline { 2 - 4 } & $\begin{array}{c}\text { Sebelum } \\
\text { Perlakuan }\end{array}$ & $\begin{array}{c}\text { sesudah } \\
\text { Perlakuan }\end{array}$ & Selisih \\
\hline \multirow{3}{*}{ Perlakuan 1 } & 3,1 & 2,8 & 0,3 \\
\cline { 2 - 4 } & 3 & 2,9 & 0,1 \\
\cline { 2 - 4 } & 2,1 & 1,8 & 0,3 \\
\hline
\end{tabular}




\begin{tabular}{llll}
\hline & 2,1 & 1,6 & 0,5 \\
\hline \multirow{3}{*}{ Perlakuan 2 } & 5,5 & 4,8 & 0,7 \\
\cline { 2 - 4 } & 3,4 & 2,7 & 0,7 \\
\cline { 2 - 4 } & 4,3 & 3,9 & 0,4 \\
\hline \multirow{3}{*}{ Perlakuan 3 } & 3,2 & 2,6 & 0,6 \\
\cline { 2 - 4 } & 5,5 & 4,4 & 1,1 \\
\cline { 2 - 4 } & 3,8 & 3,1 & 0,7 \\
\cline { 2 - 4 } & 4,2 & 3,4 & 0,8 \\
\hline
\end{tabular}

Keterangan :

Nilai Normal $: 0,5-1,4 \mathrm{mg} / \mathrm{dl}$

Hiperurisemia : $1,7-3,0 \mathrm{mg} / \mathrm{dl}$

Pada hasil penurunan kadar asam urat mencit dilakukan analisis data dengan uji ANNOVA pada tabel 5 dan Bonferroni pada tabel 6.

Tabel 5. Annova

\begin{tabular}{llccccc}
\hline Sebelum & $\begin{array}{c}\text { Sum of } \\
\text { Squares }\end{array}$ & df & $\begin{array}{c}\text { Mean } \\
\text { Square }\end{array}$ & F & Sig. \\
\hline $\begin{array}{l}\text { Between } \\
\text { Groups }\end{array}$ & 7.952 & 2 & 3.976 & 6.151 & .021 \\
\cline { 2 - 7 } & $\begin{array}{l}\text { Within } \\
\text { Groups }\end{array}$ & 5.817 & 9 & .646 & & \\
\cline { 2 - 7 } Sesudah & Total & 13.769 & 11 & & & \\
& $\begin{array}{l}\text { Between } \\
\text { Groups }\end{array}$ & 4.452 & 2 & 2.226 & 3.593 & .071 \\
\cline { 2 - 7 } & $\begin{array}{l}\text { Within } \\
\text { Groups }\end{array}$ & 5.575 & 9 & .619 & & \\
\hline & Total & 10.027 & 11 & & & \\
\hline
\end{tabular}

Dari kelompok perlakuan sebelum terdapat perbedaan yang signifikan yang ditunjukkan dengan hasil <0,05 yaitu sebesar 0,021, sedangkan pada kelompok sesudah tidak ada perbedaan yang signifikan yang ditunjukkan dengan hasil $>0,05$ yaitu 0,071 .

\section{TABEL 6. Bonferroni}

Multiple Comparisons

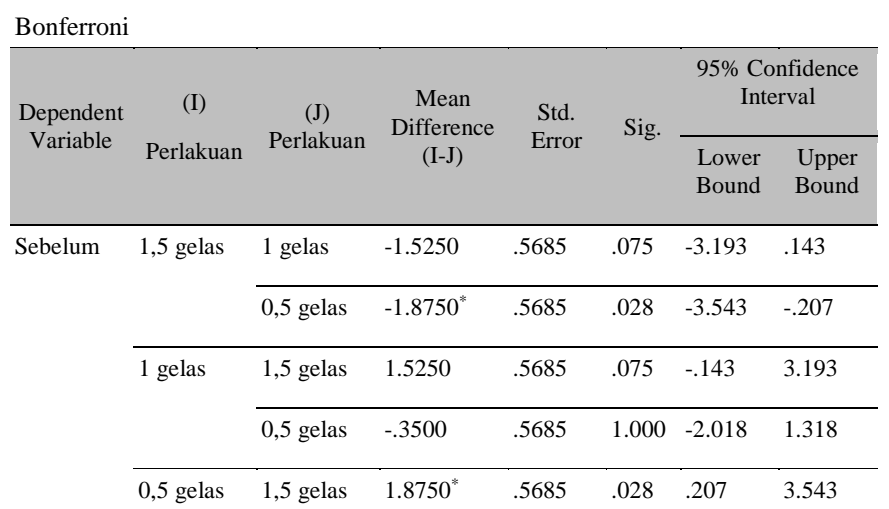

\begin{tabular}{|c|c|c|c|c|c|c|c|}
\hline & & 1 gelas & .3500 & .5685 & 1.000 & -1.318 & 2.018 \\
\hline \multirow[t]{6}{*}{ Sesudah } & 1,5 gelas & 1 gelas & -1.2250 & .5565 & . 166 & -2.857 & .407 \\
\hline & & 0,5 gelas & -1.3500 & .5565 & .115 & -2.982 & .282 \\
\hline & 1 gelas & 1,5 gelas & 1.2250 & .5565 & .166 & -.407 & 2.857 \\
\hline & & 0,5 gelas & -.1250 & .5565 & 1.000 & -1.757 & 1.507 \\
\hline & 0,5 gelas & 1,5 gelas & 1.3500 & .5565 & .115 & -.282 & 2.982 \\
\hline & & 1 gelas & . 1250 & .5565 & 1.000 & -1.507 & 1.757 \\
\hline
\end{tabular}

*. The mean difference is significant at the 0.05 level.

Perbedaan penurunan hasil asam urat yang paling baik dari 3 kelompok perlakuan yaitu perlakuan 0,5 gelas dan 1,5 gelas dengan ditunjukan adanya tanda bintang pada Uji Bonferroni.

\section{Pembahasan}

\section{Fitokimia}

Penelitian ini menganalisis adanya senyawa metabolit sekunder didalam rebusan daun kemangi dan daun salam. Hasil uji fitokimia pada daun kemangi terdapat senyawa flavonoid dan triterpenoid. Sedangkan pada daun salam terdapat senyawa flavonoid dan triterpenoid. Golongan senyawa flavonoid yang mampu menghambat kerja enzim hipoxhatin dan xantin dalam tubuh yang menyebabkan penghambatan dalam pembentukan asam urat. Selain itu juga berkhasiat sebagai diuretik yang membantu pengeluaran asam urat memalui urin (Andriani \& Chaidir, 2016).

\section{Anti-Hiperurisemia}

Penelitian ini menganalisis pengaruh dan dosis yang optimum untuk kombinasi rebusan daun salam dan daun kemangi pada mencit yang telah di induksi hiperurisemia. Sebanyak 24 mencit dibagi ke dalam 6 kelompok yaitu, 3 kelompok sebagai kelopok eksperimen dan 3 kelompok lainnya sebagai kontrol.

Induksi hiperurisemia dilakukan denganpemberian campuran pakan melinjo, hati sapi dan kecambah. Dan dilakukan penginduksian potassium oksonat. Potassium oksonat berfungsi sebagai induktor hiperurisemia. Potassium oksonat merupakan inhibitor uricase yang kompetitif untuk meningkatkan kadar (level) asam urat dengan mekanisme kerja melakukan pencegahan perubahan asam urat menjadi allantonin. Dimana alantonin bersifat larut dalam air dan dapat diekskresi melalui 
urin. Dengan dihambatnya enzim uricase oleh potassium oksonat menyebabkan asam urat akan tertumpuk dan tidak tereleminasi dalam bentuk urin (Suhendri, et al., 2014).

Berdasarkan Tabel 3 dan 4, didapatkan hasil selisih rata-rata penurunan kadar asam urat setelah diberikan kombinasi rebusan daun kemangi dan daun salam pada perlakuan 1 sebesar $0,3 \mathrm{mg} / \mathrm{dl}$, perlakuan 2 sebesar $0,6 \mathrm{mg} / \mathrm{dl}$ dan perlakuan 3 sebesar 0,825 $\mathrm{mg} / \mathrm{dl}$. Sedangkan selisih kelompok control positif sebesar $1,925 \mathrm{mg} / \mathrm{dl}$, control negatif sebesar 0,025 $\mathrm{mg} / \mathrm{dl}$.

Berdasarkan Tabel 5, didapatkan hasil analisis data menggunakan uji ANNOVA dari kelompok perlakuan sebelum terdapat perbedaan secara signifikan yang ditunjukkan dengan hasil $<0,05$ yaitu sebesar 0,021 , sedangkan pada kelompok sesudah tidak ada perbedaan yang signifikan yang ditunjukkan dengan hasil >0,05 yaitu 0,071 dikarenakan penginduksian rebusan daun salam dan daun kemangi hanya dilakukan selama satu minggu sedangkan untuk mendapatkan hasil penurunan yang signifikan harus dilakukan lebih lama daripada waktu pemaparan asam urat yang kami lakukan selama dua minggu.

Berdasarkan Tabel 6, dapat diketahui bahwa hasil analisis data menggunakan uji BONFERRONI terdapat perbedaan penurunan hasil asam urat yang paling baik dari 3 kelompok perlakuan yaitu perlakuan 0,5 gelas dan 1,5 gelas dengan ditunjukan adanya tanda bintang.

\section{KESIMPULAN}

Dari penelitian yang telah dilakukan dapat disimpulkan bahwa kombinasi rebusan daun salam dan daun kemangi mempunyai aktivitas antihiperurisemia. Aktivitas tersebut efektif pada kedua dosis yaitu 0,5 gelas dan 1,5 gelas namun untuk mendapatkan penurunan kadar (level) asam urat yang signifikan air rebusan ini harus dikonsumsi secara rutin dan waktu yang lebih lama.

\section{DAFTAR PUSTAKA}

Andriani, A., \& Chaidir, R. 2016. Pengaruh
Pemberian Air Rebusan Daun Salam (Syzygium Polyanthum) Terhadap Penurunan Kadar Asam Urat. Jurnal Ipteks Terapan. 10(2):112-119.

Darussalam, M., \& Rukmi, D. K. 2016. Peran Air Rebusan Daun Salam (Syzgium polyanthum) Dalam Menurunkan Kadar Asam Urat. Media Ilmu Kesehatan, 5(2):83-91.

Efendi, S. 2017. "Ir- perpustakaan universitas airlangga".

Ismanto, A. Y., \& Masi, G. 2016. Pengaruh Air Rebusan Daun Kemangi Terhadap Kadar Asam Urat Darah Pada Penderita Hiperurisemia Di Wilayah Kerja Puskesmas Wolaang. JURNAL KEPERAWATAN. 4(1).

Kusumayanti, G. A. D., Wiardani, N. K., \& Sugiani, P. P. S. 2014. Diet Mencegah dan Mengatasi Gangguan Asam Urat. Jurnal Ilmu Gizi. 5 (1):69-78.

Lehninger, A. L. 1982. Dasar-dasar biokimia Jilid 1. Jakarta: Erlangga.

Ngibad, K. 2019. Efektivitas Kombinasi Ekstrak Etanol Daun Bunga Matahari dan Tanaman Anting-Anting sebagai Antimalaria Secara In Vivo. Galen Medical Journal. 5(1):12-19.

Ngibad, K. 2019. Phytochemical Screening of Sunflower Leaf (Helianthus annuus) and Anting-Anting (Acalypha indica Linn) Plant Ethanol Extract. Borneo Journal of Pharmacy. 2(1):24-30.

Ningtiyas, I. F., \& Ramadhian, M. R. 2016. Efektivitas Ekstrak Daun Salam untuk Menurunkan Kadar Asam Urat pada Penderita Artritis Gout. Journal Major. 5(3):105-110.

Saifudin, A. 2014. Senyawa Alam Metabolit Sekunder Teori, Konsep, dan Teknik Pemurnian. Yogyakarta: Penerbit Deepublish.

Suhendi, A., Wahyuningtyas, N., \& Sutrisna, E. M. Uji Praklinik Antihiperurisemia Secara In Vivo Pada Mencit Putih Jantan Galur Balb-C dari Ekstrak Daun Salam (Syzigium polyanthum Walp) dan Daun Belimbing Wuluh (Averrhoa bilimbi L.). Biomedika.6(1). 


\section{BJMLT}

Utami, P., \& Lentera, T. 2003. Tanaman Obat untuk Mengatasi Diabetes Mellitus. Jakarta Selatan: AgroMedia. 